\title{
PENGARUH PENDEKATAN BERPIKIR KAUSALITIK SCAFFOLDING TIPE 2A MODIFIKASI BERBANTUAN LKS TERHADAP KEMAMPUAN PEMECAHAN MASALAH OPTIK GEOMETRI DAN KREATIVITAS SISWA KELAS XI SMAN 1 MATARAM
}

\author{
Fuad Tamami, Joni Rokhmat, I Wayan Gunada \\ Program Studi Pendidikan Fisika \\ FKIP Universitas Mataram \\ Jln. Majapahit No. 62, Mataram \\ Email: foetamami@gmail.com
}

\begin{abstract}
Scaffolding thinking approach is a specific method to facilitate students in determining cause and effect of phenomenon and identifying each cause happen in which assist are given. This research aims to investigate the effect of worksheet assisted causalitic thinking type 2a scaffolding modified approach toward student's problem solving ability (PSA) and creativity among second grade student at SMAN 1 Mataram. This research is a quasi experimental with research design is pretest posttest control group. The population in this research are all students of XI Sains with sampling method is purposive sampling. Problem solving ablility measured using PSA test. Meanwhile, creativity measured using verbal and figural test. Problem solving ability and creativity analyzed using t-test separated varians with 5\% significant level. The result of hypothesis test for problem solving ability is obtained $t_{\text {count }}>t_{\text {table }}$ and for creativity obtained $t_{\text {count }}<t_{\text {table. }}$. Based on the analysis result, it can be concluded that: (1) there is an effect of worksheet assisted causalitic thinking type 2 a scaffolding modified approach toward the student's problem solving ability in optical geometry. (2) there is no effect of worksheet assisted causalitic thinking type 2 a scaffolding modified approach toward student's creativity.
\end{abstract}

Keywords: Causalitic Thinking, Scaffolding, Problem Solving Ability, Optical Geometry, Creativity

\section{PENDAHULUAN}

Dewasa ini perkembangan dunia yang begitu pesat mengharuskan sumber daya manusianya untuk memiliki beberapa keterampilan yang sesuai dengan tuntutan pada abad ke-21. Dikutip dari Global Cities Education Network Report (2012), bahwa terdapat 5 keterampilan yang harus dimiliki oleh siswa pada abad ke-21 yaitu, kreativitas serta inovasi, berpikir kritis (critical thinking), pemecahan masalah (problem solving), pengambilan keputusan (decision making), dan metakognisi. Kemampuan pemecahan masalah sendiri merupakan dasar yang sangat diperlukan bagi siswa untuk menyelesaikan berbagai persoalan yang diberikan oleh guru di sekolah. Terutama persoalan yang berhubungan dengan fisika. Kenyataannya kemampuan pemecahan masalah ini masih menjadi salah satu kendala yang dihadapi oleh kebanyakan siswa. Kurangnya kemampuan pemecahan masalah ini patut diduga disebabkan oleh kurangnya pemahaman siswa akan konsep-konsep fisika. Hal ini diungkapkan oleh Silaban (2014) bahwa adanya hubungan yang positif dan signifikan antara penguasaan konsep dengan kemampuan memecahkan masalah. Dengan kata lain, kemampuan pemecahan masalah yang tinggi akan didapatkan apabila siswa memahami konsep-konsep yang berkaitan dengan pokok bahasan yang dipelajari. Secara garis besar, konsep menjelaskan gambaran suatu peristiwa. Pentingnya seseorang menguasai sutu konsep adalah agar ia mampu berkomunikasi, mengklasifikasikan ide, gagasan atau peristiwa yang dialaminya dalam kehidupan sehari-hari (Suranti et al, 2016).

Penguatan pada konsep-konsep fisika untuk mengembangkan kemampuan pemecahan masalah merupakan hal yang penting dalam pokok bahasan optik geometri. Optik geometri sendiri merupakan salah satu cabang fisika dasar tentang cahaya yang pengaplikasiannya banyak ditemukan dalam kehidupan sehari-hari. Konsep-konsep seperti pemantulan dan pembiasan cahaya maupun pembentukan bayangan pada cermin dan lensa merupakan topik yang menarik untuk dipecahkan permasalahannya. Akan tetapi, pada pokok bahasan optik geometri sendiri masih terdapat siswa yang merasa kesulitan dalam menyelesaikan soal. Bunawan et al (2015) juga menyatakan bahwa 
terdapat kesulitan bagi siswa untuk memecahkan permasalahan pada pokok bahasan optik geometri ini. Hal ini diduga diakibatkan karena kurangnya pemahaman siswa akan konsep dari optik geometri. Adapun hasil observasi didapatkan bahwa kesulitan siswa dalam mengerjakan soal diakibatkan oleh kurangnya latihan soal yang diberikan. Dengan kata lain, siswa merasa jika porsi latihan soal diberikan lebih banyak, maka fisika akan lebih mudah untuk dikuasai. Pergeseran pembelajaran fisika menjadi pembelajaran matematika inilah yang sering dijumpai saat ini. Pembelajaran yang diberikan lebih mengarah pada perhitungan matematis dengan menampilkan beberapa persamaan. Hal ini juga diungkapkan oleh Rokhmat (2015), bahwa guru memiliki kecenderungan untuk memperkenalkan sejumlah persamaan (rumus) pada fenomenafenomena terkait. Fakta ini menumbuhkan persepsi pada siswa bahwa fisika dipenuhi oleh rumus. Sehingga pembelajaran fisika menjadi kurang menarik dan tidak disukai oleh siswa. Padahal pembelajaran fisika dapat menjadi lebih menarik jika dalam pelaksanaannya guru membuat siswa terlibat secara aktif untuk berpikir secara terbuka (Rokhmat, 2012).

Agar siswa berpikir secara terbuka dan terlibat secara aktif, diperlukan suatu pendekatan pembelajaran yang dapat memfasilitasi siswa dalam menuangkan gagasan-gagasannya. Disinilah peran media pembelajaran menjadi sangat penting dalam proses pembelajaran itu sendiri. LKS merupakan salah satu alternatif media pembelajaran yang dapat digunakan pada pembelajaran. Pendekatan dan metode pembelajaran yang ada saat ini jarang sekali mengajak siswa untuk berpikir secara luas dan terbuka. Selain itu, LKS yang disusun oleh guru hanya memberikan permasalahan yang mengarah pada satu jawaban saja. Akibatnya, apabila diberikan soal fisika yang dimodifikasi bentuknya, siswa kesulitan untuk menjawabnya. Dengan kata lain, tertanam di mindset siswa bahwa hanya ada satu jalan untuk menyelesaikan soal tersebut. Padahal permasalahan fisika dapat diselesaikan apabila siswa mau membuka pikirannya untuk memecahkan soal secara kreatif. Sebagaimana Sugiarto (2011) menyatakan bahwa pengetahuan yang dipadukan dengan kreativitas akan menghasilkan kegeniusan. Sejalan dengan pendapat tersebut, Saparahayuningsih (2010) juga menyatakan bahwa peningkatan prestasi siswa tidak hanya bisa dilakukan melalui strategi proses pembelajaran yang mampu mengembangkan kecerdasan tetapi juga melalui strategi pembelajaran yang mampu meningkatkan kreativitas siswa. Kreativitas sendiri dapat diartikan sebagai kemampuan mengatasi masalah dengan mengeksplorasi potensi dan kemampuan sendiri (Dewi et al, 2016). Seseorang juga dikatakan kreatif apabila ide yang dihasilkan bernilai dan memiliki manfaat (Ekasari et al, 2016).

Alternatif yang dapat digunakan terkait dengan strategi di atas adalah pembelajaran yang dapat mengembangkan kemampuan siswa dalam berpikir secara luas (divergen) untuk menyelesaikan suatu permasalahan yang memiliki jawaban yang bervariasi. Salah satunya adalah pendekatan berpikir kausalitik (kausalitas dan analitik). Pendekatan berpikir kausalitik ini sendiri dalam pembelajaran fisika pertama kali dikemukakan oleh Rokhmat (2012). Diungkapkan bahwa pendekatan berpikir kausalitik merupakan strategi baru yang membiasakan siswa untuk berpikir secara terbuka. Pendekatan berpikir kausalitik ini dikemas dengan basis persoalan fisika yang berlandaskan kemampuan berpikir kausalitas dan berpikir analitik. Pada berpikir kausalitas, siswa dituntut untuk mampu menentukan komponen penyebab dan berdasarkan pada kondisi penyebab tersebut siswa dituntut untuk mampu memprediksi semua peristiwa (akibat) yang berpeluang terjadi secara deduktif. Sedangkan pada berpikir analitik, siswa dituntut untuk mampu mengidentifikasi bagaimana kondisi dari penyebab tersebut, sehingga dapat menimbulkan suatu akibat tertentu berdasarkan pengetahuan yang telah dimiliki yang meliputi konsep, prinsip, teori, dan/atau hukumhukum fisika terkait.

Berdasarkan penelitian yang telah dilakukan oleh Rokhmat (2013) telah terbukti bahwa pembelajaran fisika dengan berpikir kausalitik berpengaruh positif terhadap kemampuan pemecahan masalah. Pendekatan ini juga menganut berpikir divergen yang diharapkan mampu mengembangkan kreativitas siswa.

Akan tetapi, dalam penelitian diterapkannya pendekatan berpikir kausalitik ini masih belum berfungsi secara maksimal. Hal ini dikarenakan pola pendekatan berpikir kausalitik yang standar masih terlalu sulit bagi siswa. Melihat pengalaman dari peneliti sebelumnya, diprediksikan apabila 
pendekatan berpikir kausalitik ini diterapkan pada tingkat SMA, maka siswa akan mengalami kesulitan. Sehingga, perlu diberikan suatu bantuan berupa scaffolding pada pola berpikir kausalitik tersebut. Seperti yang disarankan oleh Rokhmat (2013), bahwa agar pada tahap selanjutnya dalam pembelajaran berbasis proses berpikir kausalitik perlu dikembangkan pola pendekatan berpikir kausalitik berbantuan tahapan (scaffolding). Hal ini juga berdasarkan hasil dari tanggapan mahasiswa dan dosen fisika mengenai pendekatan berpikir kausalitik (Rokhmat \& Setiawan, 2012). Dengan harapan, scaffolding yang diberikan akan membantu dalam mengembangkan proses berpikir kausalitas dan berpikir analitik (kausalitik) siswa.

Terdapat delapan tipe pola berpikir kausalitik berbantuan tahapan (scaffolding) yang dikemukan oleh Rokhmat (2015), yaitu tipe 1a sampai 4a dan 1b sampai $4 b$. Tipe a dan b memiliki perbedaan pada pemberian contoh penjelasannya, tipe a contoh penjelasannya tidak diberikan sedangkan $\mathrm{b}$ diberikan. Dalam penelitian ini, peneliti akan menggunakan pola berpikir kausalitik scaffolding tipe 2a, yaitu pengembangan berpikir kausalitik dengan bantuan pola utama tabel kausalitas dan diberikan sebagian akibat di dalam tabel tersebut. Kemudian siswa diminta untuk menentukan komponen-komponen penyebab dan akibat lainnya dengan jumlah yang sudah diketahui dari suatu fenomena. Selanjutnya siswa diminta untuk memberikan penjelasan bagaimana penyebab tersebut dapat menghasilkan akibat yang terjadi (Rokhmat, 2015). Pola yang digunakan pada penelitian ini adalah pola berpikir kausalitik scaffolding tipe $2 \mathrm{a}$ dikarenakan pertimbangkan sasaran penelitian yaitu siswa SMA. Berdasarkan pertimbangan itu pula, peneliti melakukan modifikasi pada pola berpikir kausalitik scaffolding tipe 2a dikarenakan pada tabel kausalitas, penyebabnya tidak satu pun diberikan. Sehingga, modifikasi yang diberikan yaitu pada tabel kausalitasnya diberikan sebagian penyebab serta jumlahnya. Pola berpikir kausalitik scaffolding tipe 2a modifikasi inilah yang akan dituangkan dalam bentuk LKS, sehingga diharapkan siswa terbantu dalam mengembangkan pola berpikir kausalitiknya.

\section{METODE PENELITIAN}

Penelitian ini termasuk penelitian quasi experimental. Penelitian ini dilakukan pada siswa SMAN 1 Mataram kelas XI MIPA yang berjumlah 70 orang dengan teknik pengambilan sampel yaitu purposive sampling. Sementara itu, desain penelitian ini adalah pretest posttest control group. Perlakuan dilakukan pada kelas eksperimen, sedangkan pembelajaran konvensional diterapkan pada kelas kontrol. Data kemampuan pemecahan masalah dikumpulkan dengan instrumen tes berupa uraian sejumlah 5 soal sedangkan data kreativitas diperoleh menggunakan tes kreativitas yang terdiri dari tes kreativitas verbal dan figural. Pengolahan data diawali dengan pengujian homogenitas pada data tes awal dan normalitas data pada data tes akhir. Kemudian hipotesis diuji dengan t-test separated varians dengan taraf signifikansi $5 \%$.

\section{HASIL DAN PEMBAHASAN}

Hasil penelitian berupa data tes awal dan tes akhir baik itu kemampuan pemecahan masalah maupun kreativitas. Penelitian ini sendiri bertujuan untuk menyelidiki pengaruh pendekatan berpikir kausalitik scaffolding tipe 2a modifikasi berbantuan LKS terhadap kemampuan pemecahan masalah optik geometri dan kreativitas siswa kelas XI SMAN 1 Mataram.

\section{A. Kemampuan Pemecahan Masalah}

Hasil tes awal dan tes akhir kemampuan pemecahan masalah untuk kelas eksperimen dan kelas kontrol pada materi optik geometri dapat dilihat dalam Tabel 1 berikut.

Tabel 1 Data Hasil Tes Awal dan Tes Akhir Kelas Eksperimen dan Kontrol

\begin{tabular}{ccccccccc}
\hline \multirow{2}{*}{ Tes } & Kelas & $\begin{array}{c}\text { Jumlah } \\
\text { Siswa } \\
\text { (N) }\end{array}$ & $\begin{array}{c}\text { Nilai } \\
\text { Max. }\end{array}$ & $\begin{array}{c}\text { Nilai } \\
\text { Min. }\end{array}$ & $\begin{array}{c}\text { Rata- } \\
\text { rata }\end{array}$ & $\mathbf{s}^{2}$ & Varians & Data \\
\hline \multirow{2}{*}{ Awal } & Eksperimen & 35 & 57 & 13 & 31.87 & 141.43 & \multirow{2}{*}{ Homogen } & - \\
& Kontrol & 35 & 60 & 13 & 29.87 & 178.83 & & Normal \\
\multirow{2}{*}{ Akhir } & Eksperimen & 35 & 83 & 33 & 56.44 & 135.23 & - & Normal \\
\hline & Kontrol & 35 & 67 & 13 & 41.87 & 224.47 & &
\end{tabular}


Tabel 1 menunjukkan bahwa siswa kelas eksperimen dan kontrol memiliki kemampuan yang sama sebelum diberikan perlakuan. Hal ini dibuktikan dengan hasil tes awal yang homogen. Setelah kedua kelas diberi perlakuan, nilai rata-rata tes akhir kelas eksperimen 56.44 lebih tinggi daripada kelas kontrol 41.87. Nilai rata-rata tes akhir menunjukkan bahwa kemampuan pemecahan masalah fisika pada pokok bahasan optik geometri kelas eksperimen dan kontrol sama-sama mengalami peningkatan. Kelas eksperimen mengalami peningkatan nilai rata-rata sebesar 24.57 sedangkan kelas kontrol mengalami peningkatan sebesar 12.00. Hasil tersebut menunjukkan bahwa peningkatan nilai rata-rata di kelas eksperimen lebih tinggi dari peningkatan nilai rata-rata kelas kontrol. Adapun hasil uji hipotesis diperoleh nilai $t_{\text {hitung }}$ lebih besar dari $t_{\text {tabel }}$ yaitu $4.5453>1.9954$. Hasil ini menunjukkan bahwa pendekatan berpikir kausalitik scaffolding tipe $2 \mathrm{a}$ modifikasi berbantuan LKS berpengaruh dalam meningkatkan kemampuan pemecahan masalah optik geometri siswa. Penelitian ini juga sesuai dengan penelitian yang dilakukan oleh Rokhmat (2016) yang menemukan bahwa pendekatan berpikir kausalitik dapat meningkatkan kemampuan pemecahan masalah mahasiswa calon guru fisika. Hasil penelitian tersebut menunjukkan bahwa implementasi dari pendekatan berpikir kausalitik ini memberikan pengaruh positif bagi kemampuan pemecahan masalah mahasiswa baik itu kelas atas maupun bawah.

Indikator kemampuan pemecahan masalah (IPM) yang dikembangkan dalam penelitian ini meliputi understanding (memahami), selecting (memilih), differentiating (membedakan), determining (menentukan), applying (menerapkan), dan identifying (mengidentifikasi). Berikut adalah rata-rata persentase ketercapaian IPM untuk siswa kelas eksperimen. Ketercapaian IPM-1 dari 35 orang siswa yaitu $98.29 \%$, IPM-2 sebesar $85.71 \%$, IPM-3 sebesar $23.43 \%$, IPM-4 sebesar $50.29 \%$, IPM-5 sebesar $23.43 \%$, dan IPM-6 sebesar $57.71 \%$ (Gambar 1). Data ini merupakan hasil dari tes akhir yang diberikan kepada siswa kelas eksperimen. Gambar 1 memperlihatkan bahwa IPM-1 (memahami) memiliki presentase yang paling tinggi karena untuk memahami maksud soal merupakan sesuatu yang paling mendasar bagi siswa. IPM-2 (memilih) juga memiliki presentase yang tinggi dari keenam indikator. Artinya kemampuan siswa dalam memilih kemungkinan jawaban yang benar dapat dikatakan tinggi. Sedangkan kemampuan siswa dalam mengidentifikasi suatu permasalahan (IPM-6) digolongkan sedang. Dari keenam IPM tersebut, faktanya terlihat tiga indikator yang mendapat persentase rendah, yaitu IPM-3, IPM-4, dan IPM-5. Hal ini menandakan bahwa kemampuan pemecahan masalah siswa pada indikator differentiating (IPM-3), determining (IPM-4) dan applying (IPM-5) masih tergolong rendah.

Pada IPM-3 siswa dituntut untuk dapat membedakan komponen penyebab yang berpengaruh terhadap suatu akibat yang terpilih dengan akibat lainnya. Kebanyakan siswa masih mengalami kesulitan dalam membedakan penyebab ini, hal ini kemungkinan disebabkan karena siswa masih terpaku pada satu jawaban saja. Selain itu, tidak terbiasanya siswa dalam berpikir divergen walaupun sudah diberikan pembelajaran yang memfasilitasinya merupakan salah satu penyebabnya. Adapun persentase dari IPM-3 untuk kelas kontrol lebih tinggi dibanding kelas eksperimen dikarenakan pada kelas kontrol terdapat beberapa siswa yang memiliki kemampuan kognitif yang tinggi dibanding siswa yang berada di kelas eksperimen. Dua IPM yang juga memiliki presentase rendah adalah IPM-4 dan IPM5. IPM-4 menuntut siswa untuk menentukan konsep, prinsip, dan/atau hukum yang berlaku untuk suatu fenomena.

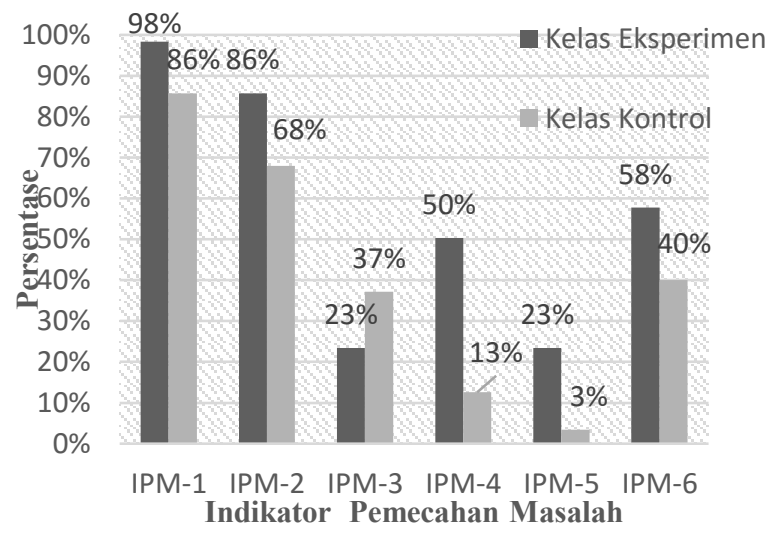

Gambar 1 Persentase Ketercapaian Indikator Pemecahan Masalah Kelas Eksperimen dan Kontrol 
Namun seperti yang ditunjukkan pada gambar di atas, siswa masih mengalami kesulitan dalam hal ini. Sebagian besar siswa masih menggunakan nalar dalam menjawab suatu permasalahan tanpa didasari dengan konsep yang benar. Hal ini juga kemungkinan disebabkan karena siswa kurang membaca literatur selama pembelajaran. Kurangnya kemampuan siswa dalam menentukan konsep tersebut juga berpengaruh pada IPM-5 yaitu kemampuan untuk mengaplikasikan konsep yang sudah ditentukan untuk digunakan dalam menjelaskan solusi dari suatu permasalahan. Bagaimanapun juga, rata-rata presentase ketercapaian indikator pemecahan masalah oleh siswa kelas eksperimen lebih tinggi dibandingkan dengan kelas kontrol. Untuk lebih jelasnya, presentase ketercapaian indikator pemecahan masalah untuk kedua kelas dapat dilihat pada Gambar 1.

Adapun hal-hal yang perlu dilakukan untuk upaya meningkatkan kemampuan pemecahan masalah pada IPM-3 sampai IPM-5 adalah dengan melakukan penekanan-penekanan pada saat pembelajaran dalam hal membedakan antara akibatakibat yang dapat terjadi dari suatu penyebab. Selain itu, menentukan konsep, prinsip, teori, dan atau hukum fisika yang digunakan untuk mendukung dalam mengidentifikasi sebuah atau beberapa penyebab sehingga menghasilkan suatu akibat. Kemudian bagaimana siswa dapat menerapkan konsep, prinsip, teori, dan atau hukum fisika tersebut, serta dapat mengidentifikasi bagaimana kondisi penyebab tersebut dapat menghasilkan suatu akibat. Dengan demikian kemampuan pemecahan masalah siswa dapat utuh secara keseluruhan.

\section{Kreativitas}

Hasil tes awal dan tes akhir kreativitas untuk siswa kelas eksperimen dan kelas control ditunjukkan pada tabel 2 berikut. Tabel 2 menunjukkan bahwa siswa kelas eksperimen dan kontrol memiliki kemampuan yang sama sebelum diberikan perlakuan. Hal ini dibuktikan dengan hasil tes awal yang homogen. Setelah kedua kelas diberi perlakuan, nilai rata-rata tes akhir kelas eksperimen 47.33 lebih tinggi daripada kelas kontrol 43.29. Adapun hasil uji hipotesis menunjukkan nilai $t_{\text {hitung }}<t_{\text {tabel }}$ yaitu $1.3121<1.9954$. Artinya bahwa pendekatan berpikir kausalitik scaffolding tipe 2a modifikasi berbantuan LKS tidak berpengaruh terhadap kreativitas siswa. Nilai $t_{\text {hitung }}$ yang kecil diduga dipengaruhi oleh selisih nilai rata-rata dari kedua kelas yang tidak terpaut jauh yaitu 47.33 untuk kelas eksperimen dan 43.29 untuk kelas kontrol.

Tabel 2 Data Hasil Tes Awal dan Tes Akhir Kreativitas Kelas Eksperimen dan Kontrol

\begin{tabular}{ccccccccc}
\hline \multirow{2}{*}{ Tes } & Kelas & $\begin{array}{c}\text { Jumlah } \\
\text { Siswa } \\
\text { (N) }\end{array}$ & $\begin{array}{c}\text { Nilai } \\
\text { Max. }\end{array}$ & $\begin{array}{c}\text { Nilai } \\
\text { Min. }\end{array}$ & $\begin{array}{c}\text { Rata- } \\
\text { rata }\end{array}$ & $\mathbf{s}^{2}$ & Varians & Data \\
\hline \multirow{2}{*}{ Awal } & Eksperimen & 35 & 56.67 & 20.00 & 34.57 & 85.02 & \multirow{2}{*}{ Homogen } & - \\
& Kontrol & 35 & 63.33 & 20.00 & 40.57 & 108.16 & & Normal \\
\multirow{2}{*}{ Akhir } & Eksperimen & 35 & 73.33 & 26.67 & 47.33 & 174.85 & - & Normal \\
\hline
\end{tabular}

Namun apabila meninjau kembali nilai ratarata tes awal yaitu, 34.57 untuk kelas eksperimen dan 40.57 untuk kelas kontrol, maka peningkatan lebih terlihat pada kelas ekperimen. Sehingga untuk keperluan analisis data lebih lanjut, digunakanlah uji $\mathrm{N}$-Gain untuk melihat apakah adanya peningkatan terhadap nilai kreativitas kedua kelas. Berikut adalah hasil uji $\mathrm{N}$-gain tiap indikator kreativitas untuk masing-masing kelas.
Tabel 3 Skor N-Gain tiap Indikator Kreativitas Kelas Eksperimen dan Kontrol

\begin{tabular}{lllcccc}
\hline & & \multicolumn{4}{c}{ Skor N-Gain } & Rata- \\
\cline { 3 - 6 } No & Kelas & IK- & IK- & IK- & IK- & rata \\
& & 1 & 2 & 3 & 4 & \\
\hline 1 & Eksperimen & 0.20 & 0.26 & 0.20 & 0.15 & 0.20 \\
2 & Kontrol & - & 0.03 & 0.05 & 0.10 & 0.04 \\
& & 0.01 & & & & \\
\hline
\end{tabular}


Berdasarkan Tabel 3, dapat dikatakan bahwa peningkatan skor untuk kelas eksperimen lebih tinggi dari pada kelas kontrol walaupun keduanya masih dalam kategori rendah. Selain itu, perbedaan antara kedua kelas dapat dilihat dari persentase ketercapaian masing-masing indikator kreativitas. Adapun persentase ketercapaian indikator kreativitas untuk kelas eksperimen dan kontrol ditunjukkan pada Gambar 2. Terlihat pada diagram tersebut, perbedaan antara keduanya tidak besar namun siswa pada kelas eksperimen memiliki presentase yang lebih tinggi dari pada siswa di kelas kontrol. Akan tetapi perbedaan yang tidak begitu besar inilah yang menyebabkan tidak terdapat pengaruh pendekatan berpikir kausalitik scaffolding tipe 2a modifikasi berbantuan LKS ini terhadap kreativitas siswa.

Secara parsial dapat dilihat pada Gambar 2 bahwa indikator yang paling tinggi persentasenya adalah indikator (flexibility) yaitu kemampuan seseorang dalam menghasilkan ide/gagasan yang beragam. Hal tersebut menunjukkan bahwa siswa sudah memiliki fleksibilitas dalam berpikir. Kemudian pada urutan kedua terdapat indikator (fluency) yaitu kemampuan seseorang dalam menghasilkan ide/gagasan yang banyak. Pada kasus ini siswa memiliki kelancaran berpikir yang masih dikategorikan rendah dilihat dari persentase ketercapaiannya. Kemudian diurutan ketiga terdapat indikator (originality) yang masih dalam kategori rendah yaitu kemampuan seseorang dalam menghasilkan ide/gagasan yang berbeda dari yang lain. Pada kasus ini siswa cenderung masih meniru atau memiliki ide yang sama dengan temannya. Terakhir adalah indikator (elaboration) yaitu kemampuan seseorang untuk menambahkan perincian terhadap ide yang dihasilkannya. Indikator ini dikategorikan rendah karena hanya beberapa siswa yang memberikan rincian pada setiap ide/gagasannya.

Pendekatan berpikir kausalitik ini seharusnya dapat berpengaruh positif terhadap kreativitas siswa. Sebagaimana dipaparkan oleh Munandar (2012) tentang hubungan antara intelegensi dengan kreativitas yaitu kemampuan berpikir divergen merupakan indikator dari kreativitas. Silaban (2014) dan Guilford (dalam Munandar, 2012) juga berpendapat bahwa kreativitas merupakan kemampuan berdasarkan data atau informasi yang tersedia untuk menemukan banyak kemungkinan jawaban terhadap suatu masalah, dimana penekanannya adalah pada kuantitas, ketepatgunaan dan keragaman jawaban. Sehingga semakin banyak kemungkinan jawaban yang dapat diberikan terhadap suatu masalah maka kreatiflah seseorang. Pendekatan berpikir kausalitik ini juga memuat konsep dari berpikir divergen yaitu di dalam proses pembelajarannya siswa dituntut untuk menemukan komponen-komponen penyebab dan akibat yang memungkinkan untuk terjadi secara luas. Tentu saja jumlah jawaban yang diberikan tidak semata-mata menentukan kreativitas seseorang tetapi juga kualitas dari jawabannya. Munandar (2012) menyatakan bahwa terdapat empat indikator kreativitas yaitu, kelancaran (fluency), fleksibilitas (flexibility), orisinalitas (originality), dan elaborasi (elaboration). Artinya jika seseorang memiliki kreativitas maka ciri-ciri di atas akan muncul pada cara berpikirnya.

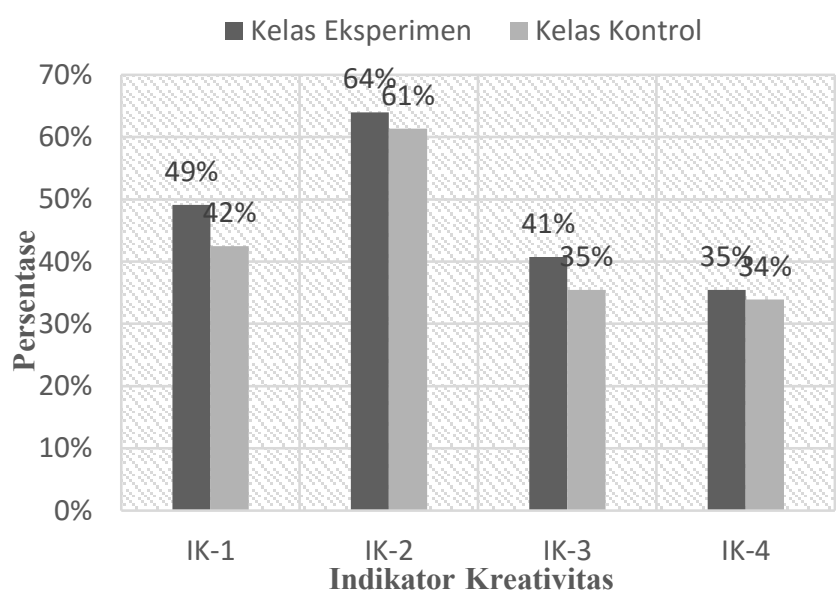

Gambar 2 Grafik Persentase Rata-rata Ketercapaian Indikator Kreativitas

Walaupun demikian, hasil penelitian ini menunjukkan tidak adanya pengaruh pendekatan berpikir kausalitik ini terhadap kreativitas. Tidak adanya pengaruh ini kemungkinan disebabkan oleh beberapa hal. Pertama, proses pengambilan data tes akhir yang terkesan terburu-buru. Hal yang dimaksudkan adalah tes kreativitas pada tes awal menggunakan perhitungan waktu dalam pengambilan datanya, sementara tes akhir tidak. Hal ini dilakukan untuk mengantisipasi kurangnya waktu dalam pengambilan data tes akhir. Penggunanaan perhitungan waktu dalam tes kreativitas dirasakan sangat penting karena hal tersebut dapat membangkitkan kreativitas di dalam diri siswa. Kim 
(2011) menyatakan bahwa dalam tes kreativitas baik itu verbal maupun figural membutuhkan waktu 30 menit untuk pengambilan datanya, sehingga kecepatan sangat diperlukan. Artinya dalam pelaksanaannya tes kreativitas memang sangat memerlukan perhitungan waktu. Kedua, suasana kelas turut mempengaruhi karena setiap siswa akan terganggu dengan kebisingan yang ditimbulkan baik oleh teman sekelasnya maupun kelas lainnya. Selan itu, pada saat proses pengambilan data tes akhir terdapat beberapa siswa yang memiliki kepentingan lain seperti ekstrakulikuler yang mendesak sehingga mempengaruhi kinerjanya saat tes. Hal ini merupakan sesuatu yang penting untuk diperhatikan agar penelitian selanjutnya dapat lebih optimal. Penyebab ketiga yaitu dampak dari pembelajaran di sekolah, maksudnya adalah belum terbiasanya siswa dengan pembelajaran yang baru seperti pendekatan berpikir kausalitik ini. Siswa masih terbiasa dengan pembelajaran yang sering diterapkan di sekolahnya.

Oleh karena itu, untuk upaya mengatasi kekurangan tersebut pada pelaksanaan tes kreativitas sebaiknya dilakukan terisah dengan tes yang lain (jika ada). Selain itu, pelaksanaan tes juga diperlukan perhitungan waktu agar kreativitas siswa menjadi maksimal.

\section{PENUTUP}

Pada taraf signifikan 5\% terdapat pengaruh pendekatan berpikir kausalitik scaffolding tipe 2a modifikasi berbantuan LKS terhadap kemampuan pemecahan masalah optik geometri siswa kelas XI SMAN 1 Mataram. Sementara tidak terdapat pengaruh untuk kreativitas.

Pendekatan berpikir kausalitik scaffolding tipe 2a modifikasi berbantuan LKS ini dapat diterapkan untuk meningkatkan kemampuan pemecahan masalah fisika dan kreativitas siswa dengan memperhatikan beberapa hal, yaitu:

1. Pemahaman siswa akan cara belajar menggunakan pendekatan ini sangat diperlukan agar proses pembelajaran berlajan dengan optimal. Sebagai contoh yaitu pemberian tugas pendahuluan yang akan membantu siswa dalam membasakan diri dengan pembelajaran kausalitik ini;
2. Alokasi waktu diatur sebaik mungkin agar setiap tahapan pembelajaran dapat berlangsung secara maksimal;

3. Dapat mengontrol siswa dengan intensif agar semua siswa dalam kelompok benar-benar bekerja sama pada saat mengerjakan LKS

4. Agar pelaksanaan tes kreativitas dapat berjalan dengan optimal, sebaiknya dilakukan secara terpisah dengan tes yang lainnya. Selain itu, diperlukan batas waktu pada pelaksanaan tes.

5. Instrumen tes kreativitas khususnya figural perlu diberikan bantuan pola awal. Hal ini bertujuan untuk memberikan stimulus kepada siswa agar imajinasinya berkembang.

6. Suasana kelas yang kondusif juga berperan aktif dalam menstimulus kreativitas siswa.

\section{UCAPAN TERIMA KASIH}

Terima kasih penulis ucapkan kepada bapak Drs. H. Lalu. Fatwir Uzali, M.Pd., selaku kepala sekolah SMAN 1 Mataram, atas izin penelitian dan fasilitas yang diberikan dan bapak Drs. Pranowo Raharjo., selaku guru mata pelajaran fisika, serta seluruh siswa kelas XI MIPA 3 dan XI MIPA 4 SMAN 1 Mataram yang telah ikut serta dalam penelitian ini. Terimakasih pula untuk kedua dosen pembimbing yang selalu memberikan bimbingan dan arahan dalam penulisan laporan penelitian ini.

\section{DAFTAR PUSTAKA}

Bunawan, W., Setiawan, A., Rusli, A., dan Nahadi. (2015). Penilaian Pemahaman Representasi Materi Optik Geometri Menggunakan Tes Diagnostik. Jurnal Cakrawala Pendidikan. No. 2.

Dewi, S. M., Harjono, A., dan Gunawan. (2016). Pengaruh Model Pembelajaran Berbasis Masalah Berbantuan Simulasi Virtual Terhadap Penguasaan Konsep dan Kreativitas Fisika Siswa SMAN 2 Mataram. Jurnal Pendidikan Fisika dan Teknologi, 2(3), 123-128.

Ekasari, R. R., Gunawan, dan Sahidu, H. (2016). Pengaruh Model Pembelajaran Langsung Berbantuan Media Laboratorium Terhadap Kreatifitas Fisika Siswa SMA. Jurnal Pendidikan Fisika dan Teknologi, 2(3), 106-110. 
Kim, K. H. (2011). The Creativity Crisis: The Decrease of Creativity Thinking Score on the Torrance Tests of Creative Thinking. Creativity Research Journal. 23(4), 285295.

Munandar, U. (2012). Pengembangan Kreativitas Anak Berbakat. Jakarta: Rineka Cipta.

Rokhmat, J dan Setiawan, A. (2012). Tanggapan Mahasiswa dan Dosen Terhadap Pembelajaran BerbasisProses Berpikir Kausalitas dan Berpikir Analitik dalam Perkuliahan Fisika. Jurnal Pijar MIPA, 8(2), 55-63.

Rokhmat, J. (2013). Kemampuan Proses Berpikir Kausalitas dan Berpikir Analitik Mahasiswa Calon Guru Fisika. Jurnal Pengajaran MIPA, 18-85.

(2015). Penerapan Pendekatan Berpikir Kausalitik Ber-scaffolding dalam Meningkatkan Kemampuan Pemecahan Masalah Hukum Newton Tentang Gerak. Prosiding Seminar Nasional Fisika.

(2017). Instrument Development of Causalitic Thinking Approach in Physics Learning to Increase Problem Solving Ability of Pre-service Teachers. AIP Conference Proceeding. p.030001-1 030001-9.

Rokhmat, J., Rusdiana, D., Setiawan, A.. (2012). Pembelajaran Fisika Berbasis Proses Berpikir Kausalitas Dan Berpikir Analitik (PBK-BA), Suatu Pembiasaan Berpikir Secara Terbuka. Seminar Nasional IX Pendidikan Biologi FKIP UNS.

Saavedra, A. R. and Opfer, V. D. (2012). Teaching and Learning $21^{\text {st }}$ Century Skills (Global Cities Education Network Report (Asia Society)). Hongkong: RAND Coorporation.

Saparahayuningsih, S. (2010). Peningkatan Kecerdasan dan Kreativitas Siswa. Jurnal Kependidikan Dasar, 1(1), 1-6.

Silaban, B. (2014). Hubungan Antara Penguasaan Konsep Fisika dan Kreativitas dengan Kemampuan Pemecahan Masalah pada Materi Pokok Listrik Statis. Jurnal Penelitian Bidang Pendidikan, 20(1), 65-75.

Sugiarto, I. (2011). Mengoptimalkan Daya Kerja Otak dengan Berpikir Holistik dan Kreatif. Jakarta: Gramedia.

Suranti, N. M. Y., Gunawan, dan Sahidu, H. (2016). Pengaruh Model Project Based Learning
Berbantuan Media Virtual Terhadap Penguasaan Konsep Peserta didik pada Materi Alat-alat Optik. Jurnal Pendidikan Fisika dan Teknologi, 2(2), 73-79.

Treffinger, D.J.,Young, G. C., Selby, E. C., and Shepardson, C. (2002). Assessing Creativity: Aguide for Educators. University of Connecticut: NRC/GT. 